\title{
Recent development and applications in electrodes for URFC
}

\author{
Junjie Chen*, Deguang Xu \\ School of Mechanical and Power Engineering, Henan Polytechnic University, Jiaozuo, Henan, China \\ *E-mail address: comcjj@163.com, comcjj@yahoo.com
}

\begin{abstract}
The design of electrodes for URFC (unitised regenerative polymer electrolyte ce As) requires a delicate balancing of transport media. Gas transport, electrons and rotons ust be cfully optimised to provide efficient transport to and from the electrochemical racis as This en is a survey of recent literature with the objective to identify common comp nents an sign a assembly methods for URFC electrodes, focusing primarily on the deve nent of a bifunctional electrocatalyst for the oxygen reduction and wa ox ion. Adv nces in unitised regenerative fuel cells study have yielded better performi xygen trocatalysts capable of improving energy efficiency with longer endurance and le performance do atation over time. Fuel cells using these electrocatalyst have a possible future as source of energy.
\end{abstract}

Keywords: URFC; Regenerative fuel cell; Electrocatalyst methods; Thin-film electrodes; Gas diffusion larar

\section{INTRODUCTION}

Today energy consu and with the present pr uction ra ur energy reservoirs could be emptied in less than a couple of hundred ye is. environ thtal situation looks even more critical if we consider a scenario where becon the main resource and the energy consumption per capita in heavily populat a developing o atries continues to increase at the same rate as today. So far around two $b$ ion $p$ gle in the world do not have access to electricity [1]. Providing such a number of peo, with ele ricity will have a major effect on the environment if fossil fuels

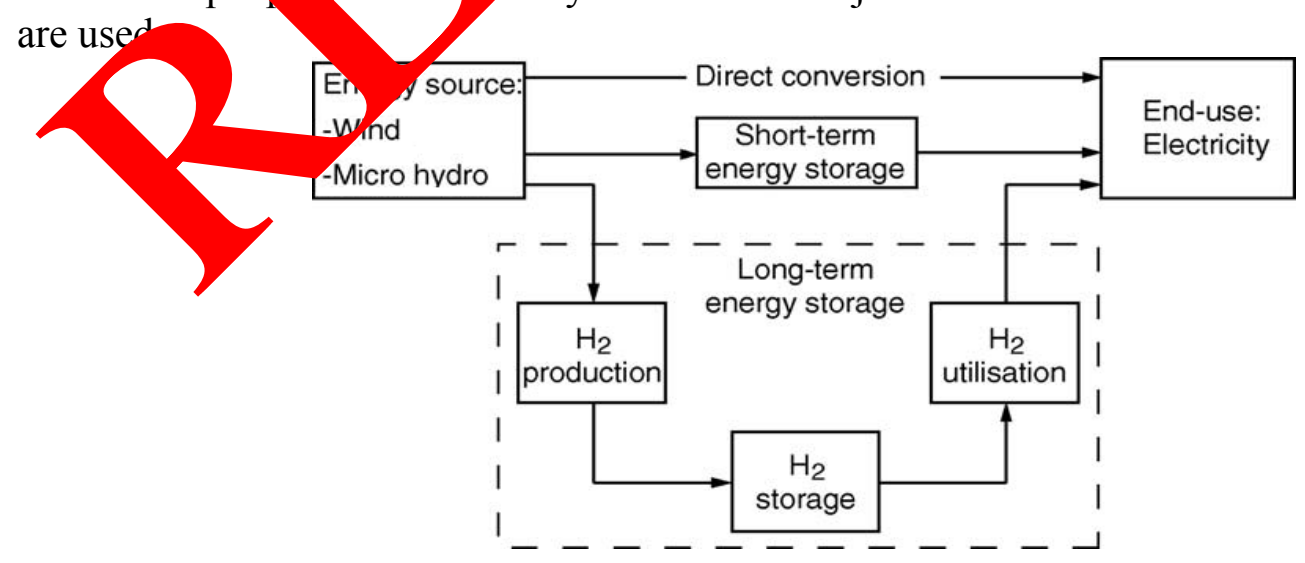

Figure 1. Schematic of energy conversions with hydrogen as a possible long-term storage. 
The frightening situation described above could to, some extent be avoided by providing remote areas with renewable energy technologies such as biomass, photovoltaics and wind turbines [2]. However, wind energy is intermittent resources, i.e. the energy availability changes from hour to hour, from day to night and from season to season. This uncertainty in energy supply could however be eliminated by connecting a local energy storage system to the production unit [3]. To some extent conventional batteries have so far been used for this purpose, but the storage cost increases significantly with storage capacity. Some scientists believe that a promising alternative to batteries would be energy storage by hydrogen, which is a pollution-free, flexible energy carrier, see Fig. 1.



Figure 2. Concept of (a) regenerativ cell (RH and (b) unitised regenerative fuel cell (URFC).

A possible storage s stem to e conversion of electrical energy consists of a hydrogen production unit, a stora edium an which converts the chemical energy stored in the hydrogen back to el trich with hel, from oxygen or air) [4]. Such a system is preferably connected to a re soble ene. surce, such as solar or wind, which provides an electrolyser cell with enou sh enc oy to split vater into hydrogen and oxygen. The gases are either stored or used dire in a $\mathrm{Mo} \mathrm{c}(\mathrm{l}$. In a fuel cell the opposite reaction to electrolysis takes place, i.e. hydrogen and o ren (or ar) are recombined to produce electricity, heat and water [5]. A systep - this, $\mathrm{b}$ oth an electrolyser and a fuel cell, is called a regenerative fuel cell ( $\mathrm{R}^{\mathrm{D}}$. A uch sma er and compact unit, see Fig. 2, is the unitised regenerative fuel cell (UR electrolyser and fuel cell are combined into one unit and only one of the two mo can be operated at one time. Usually the electrolyser is operated first to produce the hydros and oxygen, which are stored and later supplied back to the same unit when desired, which then operates as a fuel cell. Thus, a URFC is a simpler and more compact system than the RFC and it uses only one electrochemical cell [6].

Typical storage media for hydrogen and oxygen gases are either under conventional pressure vessels or in metal hydrides. Metal and liquid hydrides, such as FeTi and methanol or cyclohexane, respectively, and adsorbed carbon compounds are the principal methods of bonding hydrogen chemically [7]. They are the safest methods of storage as no hydrogen will be released in the event of an accident, but they are bulky and heavy and additional energy is also needed to release the stored hydrogen again. One of the most recent and exciting 
advances has been the announcement of carbon nanofibre technology. This may have the capacity to store up to $70 \%$ of hydrogen by weight and would be a promising storage device to be used in conjunction with a lightweight URFC system [8].

Another promising technology is self-pressurising electrolysers, which are used to supply compressed hydrogen and oxygen. This process could reduce or eliminate conventional pressure tanks all together depending on what pressure level is needed. This would be a more efficient system and a simpler and less expensive solution [9].

The key technology in the development of the PEM URFC is the fabrication of active electrocatalysts for both the oxygen reduction and the water oxidation at the oxygen electrode. The bifunctional electrocatalyst must also be resistant to anodic corrosion during the water electrolysis reaction. Several studies have reported on noble metals and metal aides, including $\mathrm{PtIrO}_{2}$ and $\mathrm{PtRuO}_{2}$, as possible catalysts for the URFC oxygen electrod $[10]$.

Recently, there has been added interest in the solid oxide regene ve fuel o (SORFC) and its higher potential for energy storage efficiency compar to low temperature systems [11]. Solid oxide electrolysers show a much lower o verpotentia an or example, the PEM electrolyser at standard pressure and $850{ }^{\circ} \mathrm{C} \mathrm{c}$ pared 80 . The higher operating temperature of the SORFC makes it ideal as a car ida on-gr and offgrid distributed energy storage and possibly as energy stor oe devicu or 3 ships and submarines with its thermal energy produced. It would not b a on any st cer scale were ambient temperature and pressure would be the main regu emen uch a system would be more suited to use the polymer electrolyte membrane 4

\section{URFC}

\subsection{Polymer electrolyte membrane}

The solid membrane in unitised regener we polymer electrolyte membrane (PEM) fuel cells is usually a perflourosulfe ac a polyn $\mathrm{r}$. This is a polytetrafluoroethylene (PTFE, trade name Teflon) chain witb che hs termivating in an $\mathrm{SO}_{3} \mathrm{H}$ group. It is the hydrogen on this sulfonate group that di cia un olymer when wet and appears as protons in the solution; polymer acids 1 ve the adv ge that the anion $\left(-\mathrm{SO}^{3-}\right.$ tail) is fixed in the electrolyte rather than dissolved 13 .

One commo P WM is con, a polymer developed by DuPont in the 1960s for use as a separator in th chlor-alkali astry and now used for other industrial electrochemical purposes. Po mer $\theta$ trolyte membranes can be made extremely thin, less than $50 \mu \mathrm{m}$, making for de ' packe stacks and, consequently, high power densities. The thinness of the PEM me migb conductance and low ohmic resistance losses [14].

Ano ir proto $x$ change membrane, the Dow membrane, is also a promising candidate for UP 


\subsection{Catalyst layer}

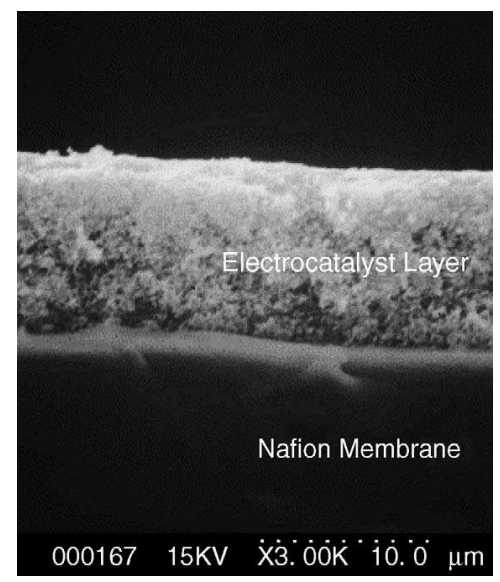

Figure 3. Scanning electron micrograph (SEM) of a cross-section of an lectroc assem

The catalyst layer in a unitised regenerative fuel cell in direc nt with the membrane and the gas diffusion layer, see Fig. 3. This lay is her applie directly to the membrane or to the gas diffusion layer with the aim to the car particles as close as possible to the polymer electrolyte membrane. Catal st layers for Uh / h have always been an important part of the development of efficient reg nerative cells [16]. Historically, Pt black has been used as the sole catalyst but later stuc has recogi ised several other suitable catalysts, including iridium (Ir), ruthenium $(\mathrm{Ru})$ a vodiun $(\mathrm{Rh})$. Study has also been concentrated on lowering the high Pt conte URFC a so st layers (typically $3-7 \mathrm{mg} \mathrm{cm}^{-2}$ ) and later study has shown that catalyst loadil as $0,4 \mathrm{mg} \mathrm{cm}^{-2}$ is possible with the help of a supported bifunctional catalyst.

\subsection{Electrode manufacture}

URFC electrode de gns ha vpicany used proven and tested methods to produce the electrode-membrane-el de inter. Most widely used is the transfer print technique followed by hot pre (an roll pross) of the design for more intimate contact of active materials. Applic on techn s like spraying, painting and casting are also used. Other emerging pron sing ethods ary chemical reduction, electrodeposition and sputter deposition, but these wi be ansu. ed here in any depth [17].

2.4.

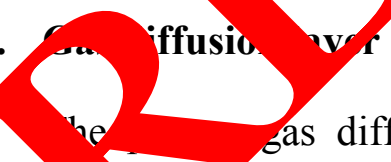

iffusion layer (GDL) in URFCs ensures an even distribution and remova reactants and products from the electrode area. It is also acting as the electrical conductor aring transport of electrons to and from the catalyst layer [18]. The GDL is also an important factor in the water management of the cell, balancing between the different properties of the fuel cell and the water electrolyser. It also plays a vital role in the hydration of the polymer electrolyte membrane. 


\section{URFC MEMBRANE-ELECTRODE ASSEMBLIES}
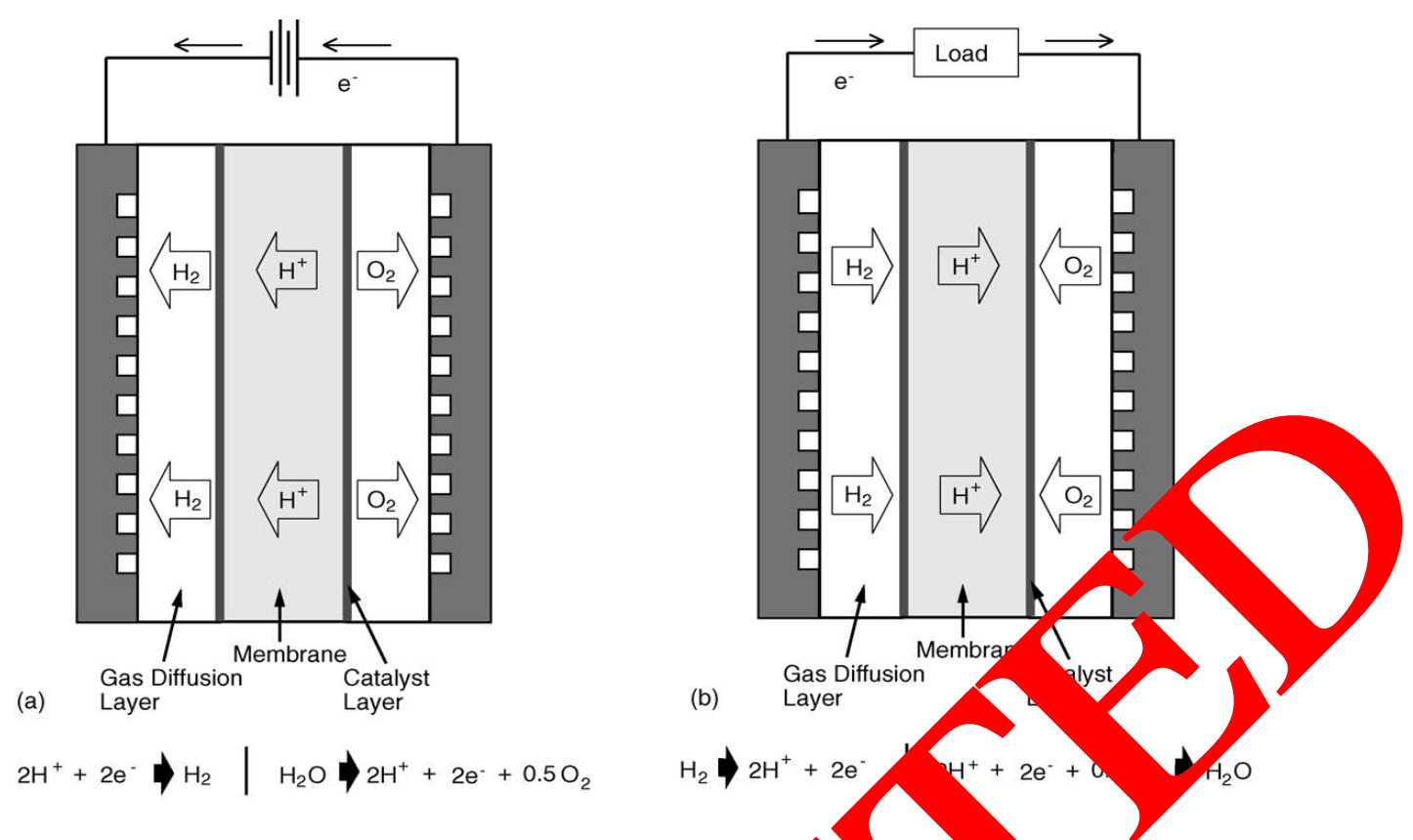

Figure 4. Schematic of a URFC with reactions, (a) PEM Crolyser (b) PEM fuel cell.

There are two problems encountered when igning ele trode structures for URFC systems [19]. For PEM fuel cells, highly hydropho wed car on paper or carbon cloth is usually adopted as the gas diffusion layer electrodo rials, however, they cannot be used as the GDL of a URFC for the followi g ansons: firstly, the carbon materials tend to corrode at high potentials on the oxyge $\mathrm{e}^{\mathrm{c}} \mathrm{ctry}$ side during the water electrolysis operation; secondly, GDLs have to hieve an appropriate balance between the hydrophobic and hydrophilic properties for b th the cell nd water electrolysis operations, as shown in Fig. 4. The fuel cell operation uire that the oxygen GDL have a hydrophobic property to prevent water flooding, or o nanu, ater electrolysis requires that the GDL have a hydrophilic property to upply wa to the oxygen electrode. Several methods have been demonstrated to ove con these pro lems by using specially designed electrodes with complex multi-laym tructu or membranes with internal fluid passages [20]. However, while these met' ods overcome Me of the basic problems, neither of these approaches leads to a cell (stac' with equate performance for use in applications.



Figure 5. Membrane-electrode assembly of typical PEM URFC. 
In a typical design of a URFC, each electrode is always in contact with the same gas, hydrogen or oxygen, and the electrical polarisation of the cell (or stack) is reversed when the system changes function, see Fig. 4. Therefore, if the unit is operating as an electrolyser, the oxygen electrode is the anode and the hydrogen electrode is the cathode [21]. If the unit is operating as a fuel cell, the oxygen electrode is the cathode and the hydrogen electrode is the anode [22]. It is therefore important when designing electrodes for URFCs that they are both designed so that they do not degrade when operated in an oxidising environment (Fig. 5).

\subsection{URFC hydrogen electrode}

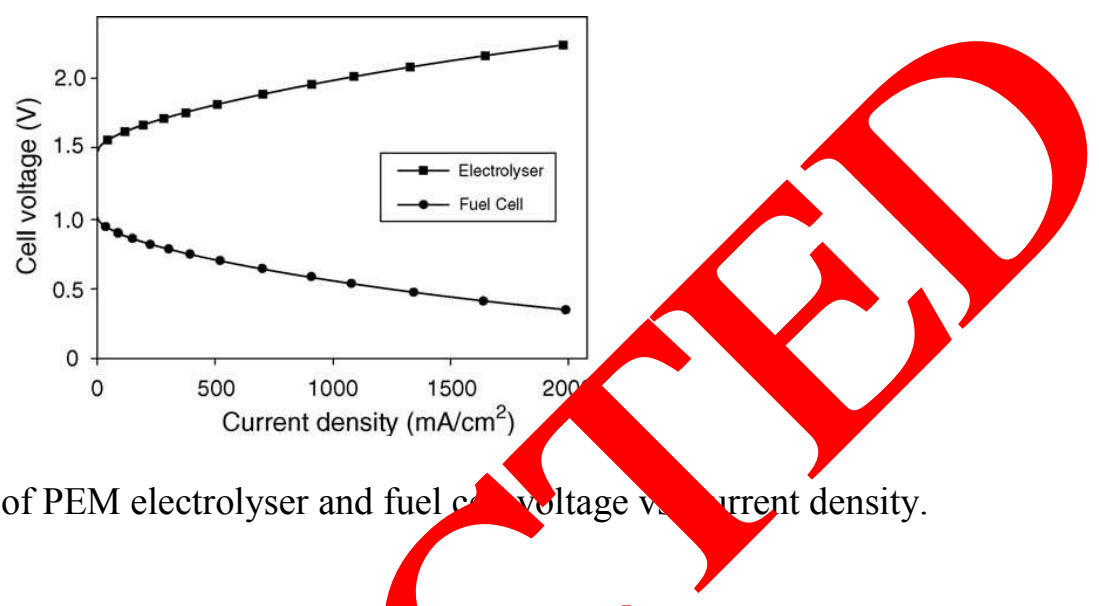

There have been many studies on suitable ctrocatalys for URFCs, however the majority of them focus on the development of a suita catalys for the oxygen electrode and only briefly discuss the formation of the hy ren electra 23$]$. This is more than likely due to the favourable kinetics of hydrogen on $\mathrm{p}$ tim the hydrogen electrode and hydrogen evolution is known to perform best with $p$ ti am the catalyst material. High current densities are realised at low overp ials, se typical current-voltage graph Fig. 6. There is no mass transport limitation an the o y restric on of the hydrogen evolving electrode is its sensitivity to poisoning. Sorie ly platinum on carbon $(\mathrm{Pt} / \mathrm{C})$ as the catalyst source for the hydrogen oxiuration nd evolution, but more recent work uses unsupported platinum black as the

\subsection{URFC oxy, electrod}

An in tant pout of the development of an oxygen electrode is the choice of electrocatalyst. well sown that the best electrocatalyst for oxygen reduction, platinum (in its fon for the best catalyst for water oxidation and oxygen evolution. Early stu by $\mathrm{uz}$ et al. 25], showed that apart from platinum, iridium oxide $\left(\mathrm{IrO}_{2}\right)$ would be a gooa n oxygen evolution, even though a relatively poor candidate as oxygen reductio atalyst. Mixed or alloyed with platinum, $\mathrm{Pt} / \mathrm{IrO}_{2}$ proved to function well as a bifunction, Yectrode catalyst. The study also identified $\mathrm{RuO}_{x}$ to be a good potential catalyst for the oxygen evolution of a bifunctional oxygen electrode. It was also found that the catalyst $\mathrm{NaxPt}_{3} \mathrm{O}_{4}$ could be a possible candidate, but further investigation would be needed. Further testing of these catalysts showed results of $0.723 \mathrm{~V}$ in the fuel cell mode and $1.587 \mathrm{~V}$ in the electrolyser mode when using $\mathrm{Pt} / \mathrm{Pt}-\mathrm{IrO}_{2}$ operated at $500 \mathrm{~mA} \mathrm{~cm}{ }^{-2}$. When using $\mathrm{Pt} / \mathrm{Pt}-$ $\mathrm{NaxPt}_{3} \mathrm{O}_{4}$ as the electrocatalyst, the performance was measured as $0.740 \mathrm{~V}$ in the fuel cell mode and $1.697 \mathrm{~V}$ in electrolyser mode, a significant improvement on the $\mathrm{Pt} / \mathrm{IrO}_{2}$ electrode.

Abdullah and Kamarudin [26] used Pt black and $\mathrm{IrO}_{2}$ as the oxygen electrode catalysts and found that $50 \mathrm{wt} . \% \mathrm{Pt}$ and $50 \mathrm{wt} . \% \mathrm{IrO}_{2}$ performed well with very low catalyst loadings 
$\left(0.4 \mathrm{mg} \mathrm{cm}^{-2}\right)$. A thin-film catalyst layer structure was used, as opposed to previously used two-layer electrode structures, in order to decrease the limitations imposed on mass transport and ohmic limitations, by the two-layer electrode structure. Performance of the cell was $0.7 \mathrm{~V}$ in the fuel cell mode and $1.71 \mathrm{~V}$ in the electrolyser mode, at $400 \mathrm{~mA} \mathrm{~cm}^{-2}, 80{ }^{\circ} \mathrm{C}$ and $0.3 \mathrm{MPa}$ and ambient pressure, respectively.

Xiao et al. [27] investigated the use of $\mathrm{IrO}_{2}$ and Pt black as feasible substitutes to the commonly used $\mathrm{Pt} / \mathrm{C}$ electrodes in PEMFC and it was found that the oxidation and reduction reactions (ORR) of oxygen were more likely on a $\mathrm{Pt} / \mathrm{IrO}_{2}$ electrode, due to higher combined surface area compared to Pt black. The overall performance of the cell seemed to change with the amount of $\mathrm{IrO}_{2}$ in the electrode. In fuel cell mode, the performance decreased with increased amount and in electrolyser mode, the performance was found to increase the amount of $\mathrm{IrO}_{2}$. A conversion efficiency of $49 \%$ was reached at a current of $000 \mathrm{~m}$, it further testing showed an increase in the efficiency to $51 \%$, which is lowe an that 0 . typical battery. The $\mathrm{IrO}_{2}$ content of the electrodes was optimised at 10-30 $\mathrm{m} / \%$.

Vivanpatarakij et al. [28] looked even further into the nature of a suitable bu ctic al electrocatalyst for URFC's by screening 715 unique combinations g ive e zents , $\mathrm{Ru}$, Os, Ir and Rh) using combinatorial chemistry. The ternary catal t ${ }^{2} \mathrm{u}_{4} \mathrm{Ir}_{0.5}$ ubscripts indicate atomic ratios) was identified to be the most efficier and sta cata yst for the oxygen electrode in a URFC system. The study showed th $/ \mathrm{u}$ ddition o $\mathrm{u}$ to the Pt/Ir electrode increased the reaction rate by stabilising the surfac atom, vgen bonds.

\subsection{Electrocatalyst supports}

The importance of the catalyst support has bee rell record ed [29]. Characteristically, a support provides a physical surface for disparsion of s, articles, which is necessary to achieve high surface area. Additional ro typically be wettability and to provide good electronic conductivity. In fuel cell $\mathrm{s}$, ter,$\%$ on has generally been used as the innocent conductive support with minor inter rence with the supported metal particles and the surface functional groups. Carbo as sup rts was primarily introduced to reduce the noble metal loadings within $t^{\prime}$ ells. Loadings nave to date been reduced from ca. 7 to 0.1 $0.2 \mathrm{mg} \mathrm{cm}^{-2}$ in hydrogen/0 an carbon at the fuel cell cathode limits the prac al lifetim the supported catalyst [30]. High potentials at the oxygen electrode in $V \mathrm{KF}$, uring ele, olysis mode lead to severe carbon corrosion.

Work has ban epor on the use of electronically conductive carbon substitutes in fuel cell systen $s$, these inclua fron carbide, tantalum boride, titanium carbide and some perovskite cr pound 31 . Conductive oxide supports, particularly reduced titanium oxides and titanium-1 num ox le composites have been used in electrolysers and are important candid for usu the xygen electrodes of URFCs.

Park al. [3. ecently examined potential electrocatalysts and oxide supports. They 100. at mhinations of the catalysts $\mathrm{Pt}, \mathrm{Ir}, \mathrm{Ru}, \mathrm{Os}$ and $\mathrm{Rh}$ on one or more of the following three tes: Luonex (primarily composed of $\mathrm{Ti}_{4} \mathrm{O}_{7}$ ), phase-pure microcrystalline $\mathrm{Ti}_{4} \mathrm{O}_{7}$ and $\mathrm{Ti}_{0.9} \mathrm{Nb}_{0.1}$ a doped rutile compound. They measured stability and activity on the different catalysts an found that the highest levels of activity and stability were in the Pt-Ru-Ir ternary region at compositions near $\mathrm{Pt}_{4} \mathrm{Ru}_{4} \mathrm{Ir}$. Due to the short-lived electrochemical stability of $\mathrm{Ti}_{4} \mathrm{O}_{7}$ and Ebonex at oxygen evolution conditions above $1.6 \mathrm{~V}$ versus RHE in $0.5 \mathrm{M} \mathrm{H}_{2} \mathrm{SO}_{4}$ (aq), there is a gradual loss of current associated with these supports. In addition, Ebonex and $\mathrm{Ti}_{4} \mathrm{O}_{7}$ underwent thermal oxidation at temperatures above $400{ }^{\circ} \mathrm{C}$ and it was found that support composed of $\mathrm{Ti}_{0.9} \mathrm{Nb}_{0.1} \mathrm{O}_{2}$ was resistant to both electrochemical and thermal oxidation.

Flick et al. [33] have developed a direct deposition of Pt catalyst onto the solid membrane using a thin-film catalyst layer impregnated with polypyrrole (ppy). Polypyrrole proved to improve the fabrication of the catalyst layer directly on to the surface of the Nafion 
membrane and overall improved the performance of the URFC. Results showed a fuel cell performance of $190 \mathrm{~mA} \mathrm{~cm}^{-2}$ at $0.695 \mathrm{~V}$ (with a catalyst loading of $0.38 \mathrm{mg} \mathrm{cm}^{-2}$ ) and 250 $\mathrm{mA} \mathrm{cm}{ }^{-2}$ at $2.0 \mathrm{~V}$ at ambient pressure and $60^{\circ} \mathrm{C}$ for the water electrolyser.

Alternatively, other oxygen reduction electrocatalysts can be used in substitution for, or in combination with, platinum [34]. An important consideration is that the oxygen reduction electrocatalyst must be stable to degradation under oxygen evolution conditions while the URFC is operating in fuel cell mode.
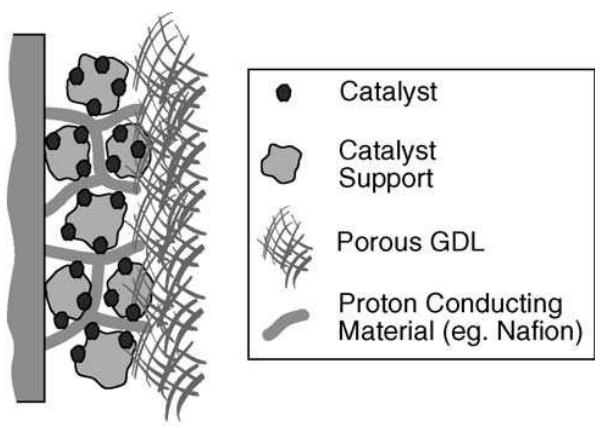

Figure 7. Schematic of typical URFC membrane-

Additionally, an effective electrode has each of least one other electronically conducting particle so the electrical conducting current collector. It also ha catalyst particle to the membrane (see Fig. 7). Som vestigat ors have developed complex arrangements with a variable internal stru to achm nese properties. It would be an advantage for an electrode to have a simple arment, with the same gross composition used throughout the volume of the electrode, i aking ity impler to fabricate.

\subsection{Gas diffusion layer}

In addition to select an en rocataryst for the development of URFC electrodes, it is vital to develop a porg conductiv aydiffusion layer to ensure an even distribution and removal of reactant and ducts from the entire electrode area to ensure uninterrupted electrical contact tween ct nt collector/distributor and electrodes [35]. In conventional PEM fuel cello this $<$ common carried out by a porous carbon matrix structure, commonly carbon pap car oos oth, this is however not suitable for long-term use in a URFC electrode struc due to kidation of carbon during the water electrolysis. Even though the oxidat te is a considerable amount of time in use, enough carbon will have bee const ied to re ace electrical contact in the MEA and thus affect the performance of the cell.

1. metal material(s) of the GDL provides both strength for the electrode structure as well as a Atinuous electrical contact between the current collecting structure and the electrodes [36]. The porous nature of the GDL material must also ensure effective diffusion of each reactant gas and water to the catalyst on the membrane-electrode assembly. The structure of the GDL must also allow the gas to spread out so that the gas and water will be in contact with the entire surface area of the membrane. In a conventional PEMFC the GDL is usually wet-proofed to assist in the water management in the MEA of the cell. In URFCs, as mention earlier, the GDL has to achieve an appropriate balance between the hydrophilic and hydrophobic properties for both fuel cell and the water electrolyser. 
The gas diffusion layer is most likely to be a woven metal cloth, expanded metal sheet; perforated metal sheets or metal foam and useful materials for the GDL of a URFC include titanium, zirconium, hafnium, niobium and tantalum. Doddathimmaiah and Andrews [37] looked at using titanium, which is a corrosion-resistive and electron-conductive material in highly cathodic and acidic environments, as the GDL for URFCs. In the study, a variety of titanium GDLs coated with different amounts of hydrophilic solution, polytetrafluoroethylene, were prepared and tested. The study found that hydrophilic content of the hydrogen GDL did not effect the cell performance, on the other hand, the amount of hydrophilic content of the oxygen GDL changed the performance of the URFC significantly. It showed that a loading of $16 \mathrm{mg} \mathrm{cm}^{-2}$ was the most appropriate on the oxygen GDL, however more testing would be needed to evaluate practical durability.

Oxidation resistant alloys are also useful materials for GDLs, such as sta inless s Inconels (predominately nickel and chromium) and Hastelloys (predominate rickel). A of use are precious metals such as platinum, gold, ruthenium, iridium an palı m. Oth metals and alloys such as nickel, aluminium and copper are useful as we 1, as long a hey are protected from oxidation through coatings.

Another approach to this type of structure is a gas diffusion act GDE) $\mathrm{n}$ a GDE the catalyst (with or without support material) and the GDL is combined to or structure. The advantage of this type of structure is that the porous co ic ive matrix acture of the GDL can be incorporated into the electrocatalyst layer of th MEA vice versa. This would lead to a significantly thinner and lighter structure, har ing same supert as the individual layer structures, and also a significant eduction in manu acturing costs.

\section{URFC MEA MANUFACTURING MFTHODS}

Conventional membrane-electrode asse $\mathrm{bbl}^{\mathrm{S}} \mathrm{e}$ EMFC are usually comprised of a $\mathrm{Pt} / \mathrm{C}$ catalyst layer and a gas diffucion lay . But the conventional membrane-electrode assembly is not commonly appled to ater elc trolysis because the gas diffusion layer may inhibit the diffusion of reacta' nd $p$ oducts. Due to this reason, most MEAs used in URFC are constructed of two-la st re murodes consisting of the membrane and a gas diffusion electrode. The $\mathrm{DE}$ is mo ommonly a thin-film electrocatalyst layer and consists of a catalyst, a protor con ting poly er and a solvent.

Typically, U gas 'usion electrodes are hot-pressed (following transfer printing) to each side of ne membrane to $1 \mathrm{~m}$ the MEA [38]. However, the catalyst loading in the rollpress methor very $\left(8-10 \mathrm{mg} \mathrm{cm}^{-2}\right)$, thus other methods like the transfer print technique, followed by ho ess is b jinning to take over, see Fig. 8. In the transfer print technique, a thin ca laye nnta ing the ionomer as the resin (binder) is first applied to a Teflon blar shee o form. acal and then transferred to the membrane by hot-pressing where after the 5 . develo by the same study group, applied the catalyst directly to the membrane. The catalyst, ended in an ink containing an alcoholic solvent, was painted onto a dry membrane and allowed to dry on a vacuum table before being turned over and the second catalyst layer was applied. In order to allow intimate contact with the membrane, high pressing temperatures and pressures were employed. However, the membrane in its protonconducting $\mathrm{H}^{+}$form could not withstand these harsh processing conditions so instead a more rigid form of the membrane is used, the ion exchange so called $\mathrm{Na}^{+}$form. The MEA is then converted back to its proton-conducting $\mathrm{H}^{+}$form by boiling the membrane in sulfuric acid. 


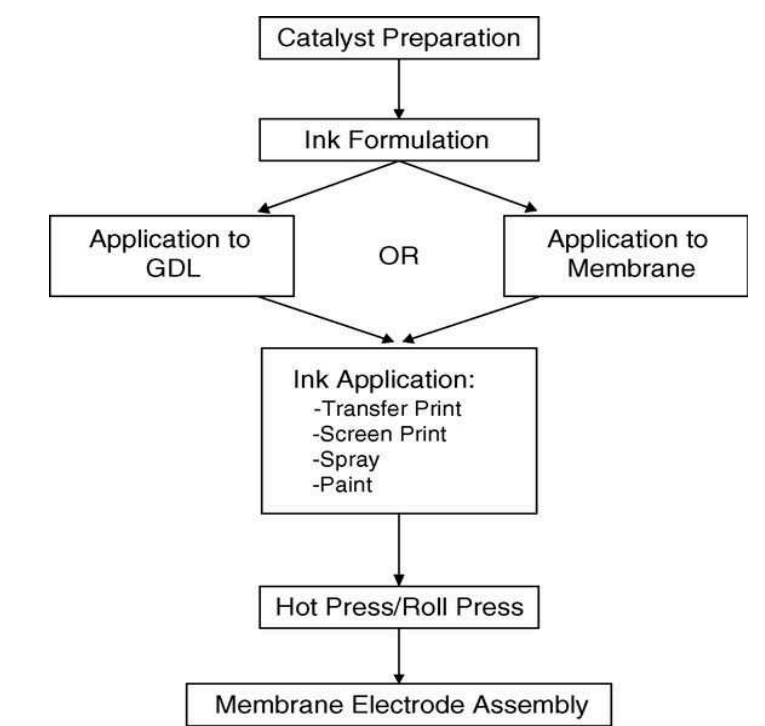

Figure 8. Flow diagram of URFC MEA assembly

Other techniques, widely used in the manufacturing of $\mathrm{CA}$ and promising candidates in the URFC field are screen-printing, chemical ro tion meth mpregnation techniques and sputter deposition but still to date, the trap er a or the ho-press methods are the most widely used within the URFC field, but the thods un need to be developed further to make hydrogen energy systems, based on EM technology, calistic contestants to modern day batteries.

\section{CONCLUSION}

This report outlined a review of recent ances made in the field of electrodes and electrocatalysts for unitised regen approach to manufacture of the ectro e structu for the URFC is a thin-film approach using the transfer print technique $r$ followed by hot pressing of the catalyst layer and the solid polymer m mbrane $h$ rm the MEA of URFC. The ability of the interface to conduct protons from a a catalyst layer and the catalyst sites is crucial, and thin-film layered st cture ve shown promise for low catalyst loadings with adequate performance. $\mathrm{O}^{1}$ er promising $\%$ ication techniques for URFC MEAs are sputter deposition and chemical educti $\checkmark$, but mo study needs to be done into these fields if these particular type of fuef co to be viable replacement technology to batteries.

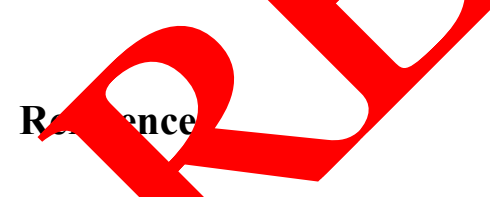

[1] Zh F.Andreasen S.J., Kær S.K., Yu D., Analysis of accelerated degradation of a HTPEM ael cell caused by cell reversal in fuel starvation condition. International Journal of Hydrogen Energy 40(6) (2015) 2833-2839.

[2] Shukla S., Domican K., Karan K., Bhattacharjee S., Secanell M., Analysis of Low Platinum Loading Thin Polymer Electrolyte Fuel Cell Electrodes Prepared by Inkjet Printing. Electrochimica Acta 156(0) (2015) 289-300.

[3] Zhang L., Zhu X., Kashima H., Li J., Ye D.-d., Liao Q., Regan J.M., Anolyte recirculation effects in buffered and unbuffered single-chamber air-cathode microbial fuel cells. Bioresource Technology 179(0) (2015) 26-34. 
[4] Hong T., Chen F., Xia C., Barium carbonate nanoparticle as high temperature oxygen reduction catalyst for solid oxide fuel cell. Electrochemistry Communications 51(0) (2015) 93-97.

[5] Wang J., Barriers of scaling-up fuel cells: Cost, durability and reliability. Energy 80(0) (2015) 509-521.

[6] Altmann S., Kaz T., Friedrich K.A., Bifunctional electrodes for unitised regenerative fuel cells. Electrochimica Acta 56(11) (2011) 4287-4293.

[7] Banan R., Bazylak A., Zu J., Combined effects of environmental vibrations and hygrothermal fatigue on mechanical damage in PEM fuel cells. International Journal of Hydrogen Energy 40(4) (2015) 1911-1922.

[8] Giddey S., Badwal S.P.S., Kulkarni A., Munnings C., A comprehensive $r$ iew of dì carbon fuel cell technology. Progress in Energy and Combustion Science (3) (201 360-399.

[9] Grigoriev S.A., Millet P., Dzhus K.A., Middleton H., Saetre T Fate V.N., Nesign and characterization of bi-functional electrocatalytic laye for olicatio in PEM unitized regenerative fuel cells. International Journal Hydroga Fne gy 35(10) (2010) 5070-5076.

[10] Grigoriev S.A., Millet P., Porembsky V.I., Fateey ., Devo ment and preliminary testing of a unitized regenerative fuel cell bo sed on PEM tec nology. International Journal of Hydrogen Energy 36(6) (2011) 416 -4168.

[11] Abd El Monem A.A., Azmy A.M., Mahmoud . Effect of process parameters on the dynamic behavior of polymer electulyte men, uel cells for electric vehicle applications. Ain Shams Engineering o 5(1) (2014) 75-84.

[12] Roca-Ayats M., García G., Galante .L., eña M.A., Martínez-Huerta M.V., Electrocatalytic stability based upported $\mathrm{Pt}_{3} \mathrm{Ir}$ nanoparticles for unitized regenerative fuel cells. Ir rrnatz, lal Jour, 1 of Hydrogen Energy 39(10) (2014) 54775484 .

[13] Nasani N., Ramas vy D., An s I, Perez J., Fagg D.P., Electrochemical behaviour of $\mathrm{Ni}-\mathrm{BZO}$ and $\mathrm{N}^{-}-\mathrm{B}_{2}$ cermet a odes for Protonic Ceramic Fuel Cells (PCFCs) - A comparative tu y. Ele chimica Acta 154(0) (2015) 387-396.

[14] Bozbağ s.E., ( ت̈müşoğlu ., Y1lmaztürk S., Ayala C.J., Aindow M., Deligöz H., Erkey C., E ch mical performance of fuel cell catalysts prepared by supercritical deposition ffect of different precursor conversion routes. The Journal of Supercritical

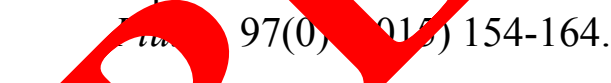

[10, 7hu $x$ Sui S., Zhang J., Electrode structure optimization combined with water ing modes for Bi-Functional Unitized Regenerative Fuel Cells. International Jou J f Hydrogen Energy 38(11) (2013) 4792-4797.

[16] Andrews J., Seif Mohammadi S., Towards a 'proton flow battery': Investigation of a reversible PEM fuel cell with integrated metal-hydride hydrogen storage. International Journal of Hydrogen Energy 39(4) (2014) 1740-1751.

[17] Gurrola M.P., Gutiérrez J., Rivas S., Guerra-Balcázar M., Ledesma-García J., Arriaga L.G., Evaluation of the corrosion of Sb-doped $\mathrm{SnO}_{2}$ supports for electrolysis systems. International Journal of Hydrogen Energy 39(29) (2014) 16763-16770. 
[18] Elmer T., Worall M., Wu S., Riffat S.B., Fuel cell technology for domestic built environment applications: State of-the-art review. Renewable and Sustainable Energy Reviews 42(0) (2015) 913-931.

[19] Meng X., Yan W., Yang N., Tan X., Liu S., Highly stable microtubular solid oxide fuel cells based on integrated electrolyte/anode hollow fibers. Journal of Power Sources 275(0) (2015) 362-369.

[20] Deleebeeck L., Arenillas A., Menéndez J.A., Kammer Hansen K., Hybrid direct carbon fuel cell anode processes investigated using a 3-electrode half-cell setup. International Journal of Hydrogen Energy 40(4) (2015) 1945-1958.

[21] Siracusano S., Baglio V., Stassi A., Ornelas R., Antonucci V., Aricò A.S., In rion of $\mathrm{IrO}_{2}$ electrocatalysts prepared by a sulfite-couplex route for the $\mathrm{O}_{2}$ evol tion rea in solid polymer electrolyte water electrolyzers. International Jourka fHydrog Energy 36(13) (2011) 7822-7831.

[22] Kim K.N., Kang J.H., Lee S.G., Nam J.H., Kim C.-J., Lattice B Itzma simu. of liquid water transport in microporous and gas diffusion layers yor yectrolyte membrane fuel cells. Journal of Power Sources 278(0) (20 s) $03-$

[23] Wittstadt U., Wagner E., Jungmann T., Membrane e co te assemb for unitised regenerative polymer electrolyte fuel cells. Journgl Pow Sources 145(2) (2005) 555-562.

[24] Matos B.R., Isidoro R.A., Santiago E.I., Ta ares A.C., Ferlauto A.S., Muccillo R., Fonseca F.C., Nafion-titanate nanotubes com sites prepal d by in situ crystallization and casting for direct ethanol fuel cells. Internd al Jour al of Hydrogen Energy 40(4) (2015) 1859-1867.

[25] Cruz J.C., Baglio V., Siracusano S., On elàs Mrriaga L.G., Antonucci V., Aricò A.S., Nanosized $\mathrm{Pt} / \mathrm{IrO}_{2}$ electrocatalyst prepar do sy mo afied polyol method for application as dual function oxygen electro unitize regenerative fuel cells. International Journal of Hydrogen Energy 37(7 (201) 5508-5, 7.

[26] Abdullah N., Kamary n dioxide in fuel cell technology: An overview. Journal of Power urces $2 \lambda$ (2015) 109-118.

[27] Xiao J., Zhang N., רg C., Ch B., Pu J., Jian L., Oxidation of $\mathrm{MnCu}_{0.5} \mathrm{Co}_{1.5} \mathrm{O}_{4}$ spinel coated SUS 9 alloy connect in anode and cathode atmospheres for intermediate temperaty e solid oxide 1 cell. International Journal of Hydrogen Energy 40(4) (2015) 68-18

[28] Vivanpata. ij S., Mouache F., Assabumrungrat S., Performance of an improved vn nation nit of Pd-membrane methane steam reformer and intermediate temp ature so d oxide fuel cell (C-Pd-ITSOFC). International Journal of Hydrogen 2015) 1894-1901.

[29] Gu . Fu G., Zhang Z., Performance of mixed-species biocathode microbial fuel cells using saline mustard tuber wastewater as self-buffered catholyte. Bioresource Technology 180(0) (2015) 137-143.

[30] Yazdi H., Alzate-Gaviria L., Ren Z.J., Pluggable microbial fuel cell stacks for septic wastewater treatment and electricity production. Bioresource Technology 180(0) (2015) 258-263.

[31] Jamil S.M., Othman M.H.D., Rahman M.A., Jaafar J., Ismail A.F., Li K., Recent fabrication techniques for micro-tubular solid oxide fuel cell support: A review. Journal of the European Ceramic Society 35(1) (2015) 1-22. 
[32] Park S., Lee J.-W., Popov B.N., A review of gas diffusion layer in PEM fuel cells: Materials and designs. International Journal of Hydrogen Energy 37(7) (2012) 58505865 .

[33] Flick S., Dhanushkodi S.R., Mérida W., Transport phenomena in polymer electrolyte membrane fuel cells via voltage loss breakdown. Journal of Power Sources 280(0) (2015) 97-106.

[34] Gabbasa M., Sopian K., Fudholi A., Asim N., A review of unitized regenerative fuel cell stack: Material, design and research achievements. International Journal of Hydrogen Energy 39(31) (2014) 17765-17778.

[35] Cruz J.C., Rivas S., Beltran D., Meas Y., Ornelas R., Osorio-Monreal G., Orti- L., Ledesma-García J., Arriaga L.G., Synthesis and evaluation of ATO as a s pport for $\mathrm{IrO}_{2}$ in a unitized regenerative fuel cell. International Journal of Hy ven Ener 37(18) (2012) 13522-13528.

[36] Zhou N., Yang C., Tucker D., Pezzini P., Traverso A., Transfer fy ction velop at for control of cathode airflow transients in fuel cell gas tu e nybrid systems. International Journal of Hydrogen Energy 40(4) (2015) 19 51-1979.

[37] Doddathimmaiah A., Andrews J., Theory, modelling ad formance easurement of unitised regenerative fuel cells. International Jov of rogen Energy 34(19) (2009) 8157-8170.

[38] Dihrab S.S., Sopian K., Alghoul M.A., Sulai an M.Y., Review of the membrane and bipolar plates materials for conventional and $\mathrm{u}$ ized regen rative fuel cells. Renewable and Sustainable Energy Reviews 13(6-7) (2009,
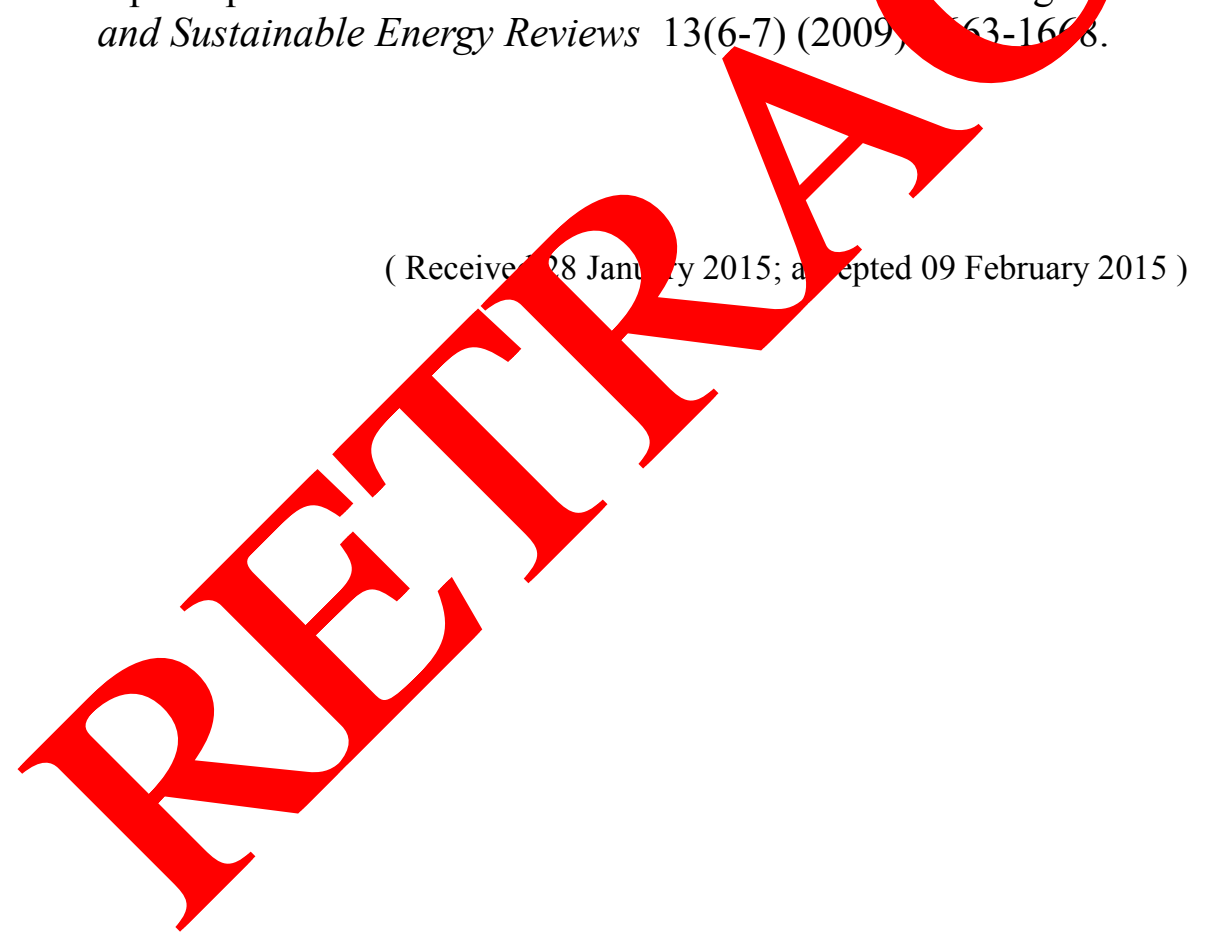